\title{
Permeability Prediction Using Hydraulic Flow Units: Baltim North Gas Field, Nile Delta, Egypt
}

\author{
Abdel Moktader A. El Sayed'1, Samy Zayed², Nahla A. El Sayed ${ }^{3}$ \\ ${ }^{1}$ Department of Geophysics, Ain Shams University, Cairo, Egypt \\ ${ }^{2}$ Belayim Petroleum Company, Nasr City, Cairo, Egypt \\ ${ }^{3}$ Egyptian Petroleum Research Institute, Department of Core analysis, Nasr City, Egypt \\ Email:moktader@sci.asu.edu.eg, samyzayed@petrobel.org,nahlamoktader@hotmail.com
}

How to cite this paper: El Sayed, A.M.A., Zayed, S. and El Sayed, N. (2021) Permeability Prediction Using Hydraulic Flow Units: Baltim North Gas Field, Nile Delta, Egypt. International Journal of Geosciences, 12, 57-76

https://doi.org/10.4236/ijg.2021.122005

Received: December 26, 2020

Accepted: February 2, 2021

Published: February 5, 2021

Copyright (c) 2021 by author(s) and Scientific Research Publishing Inc. This work is licensed under the Creative Commons Attribution International License (CC BY 4.0).

http://creativecommons.org/licenses/by/4.0/

\begin{abstract}
168 core samples data of two production wells in the Baltim North field were used to identify the complex discrepancies in reservoir pore geometry which governing the Abu Madi reservoir fluid flow properties. Permeability prediction from well logs is significant goal when the core data is rarely available in most cases because of its expensive cost. The hydraulic flow unit approach was used to classify reservoir rocks according to its pore aperture size in the cored wells. The predicted permeability was calculated from core porosity and core permeability relationship for each flow unit. The difference between Neutron porosity and Density porosity was recognized to distinguish different hydraulic flow units. The higher difference indicates higher quality flow unit and vice versa. For model's verification the predicted permeability was plotted against the laboratory measured permeability in all studied wells and shows highly matching.
\end{abstract}

\section{Keywords}

Permeability, Hydraulic Flow Units, Pore Throat (r35), Baltim Gas Field, Egypt

\section{Introduction}

Baltim Fields are one of the gas fields in the offshore Nile Delta [1]. They were discovered by IEOC in 1993 through well Baltim East-1 and in 1995 through well Baltim North-1. The field has been developed by 12 production wells in Baltim east field and 7 wells in Baltim North field. The production in Baltim fields is obtained from Abu Madi Formation of the late Messinian age. The stratigraphic units of the Neogene-Quaternary succession of the study area, which was recognized by El Heiny [2] are shown in Figure 1. 


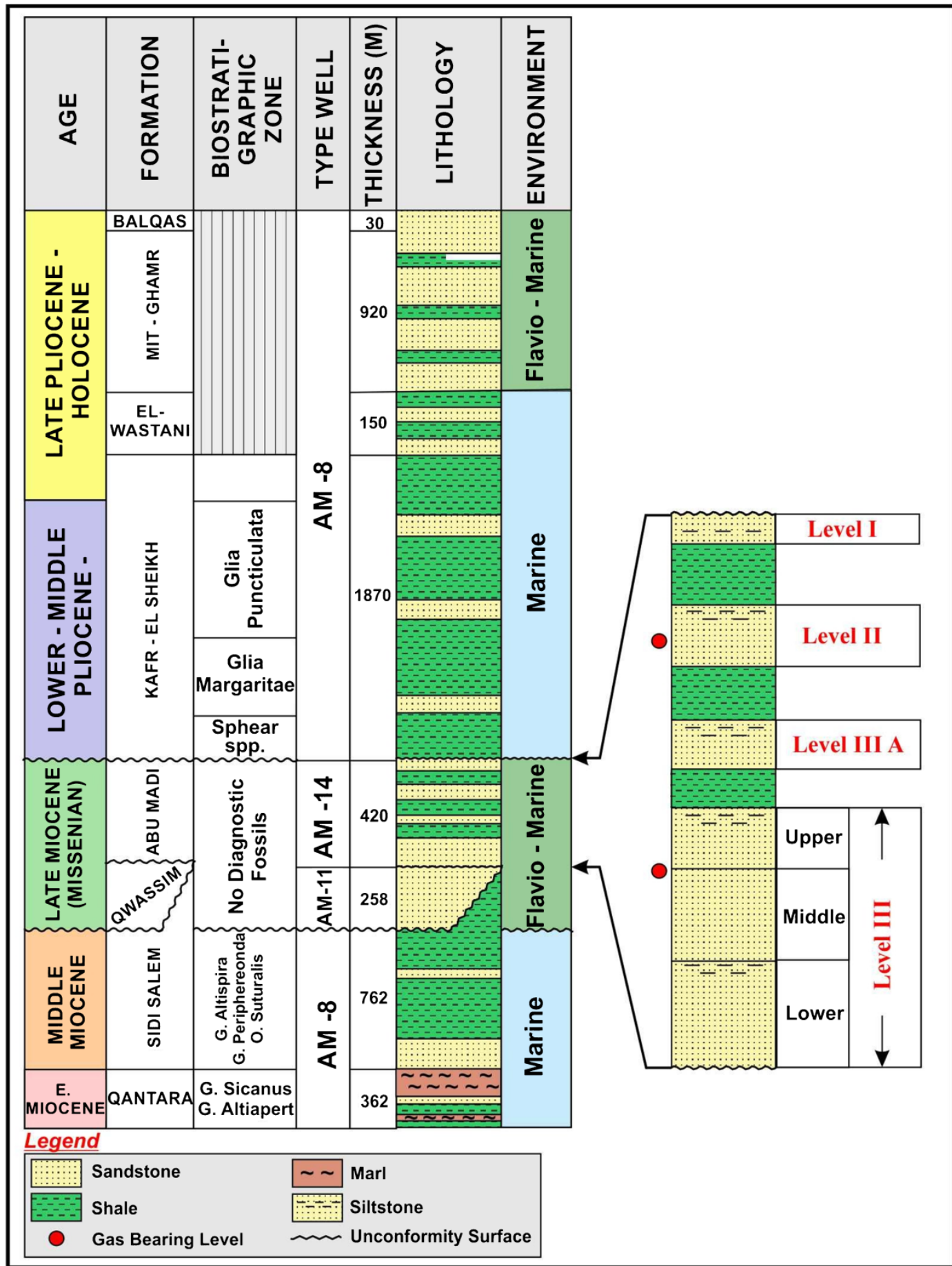

Figure 1. Schematic stratigraphic column of Baltim Field, Nile Delta [2].

Permeability is an essential parameter for hydrocarbon production performance. Permeability prediction in un-cored wells is still a great challenge. Many correlations have been constructed in literature to link this parameter to conventional downhole measurements and petrophysical properties. None of the current available open hole logs can predict the permeability value, even the most advanced NMR logging tool. 
There are many ways for rock classification into flow units. Among them, there are two famous approaches for the rock typing, Flow Zone Indicator (FZI) and Winland equation (r35).

Amaefule, et al. [3] used FZI as a new practical and theoretical based technique to identify and characterize units with similar pore throat geometrical attributes (hydraulic units). This technique has a wide variety of practical field application for both cored and uncored wells and for permeability prediction in uncored wells.

Gunter, et al. [4] used Winland equation for rock typing and permeability estimation in carbonate and complex systems. They used Winland equation specific because in many reservoirs the shape of well log-based water saturation versus depth and shape of pore throat radius versus depth are similar, in hydrocarbon column, departures in those two curves can be significant to understanding reservoir zonation.

Yangfan, et al. [5] established classification and evaluation chart with r35, permeability and porosity for limestone gas field. Dissolution is the most significant factor, which influences the heterogeneity of the reservoir. The reservoir classification and evaluation chart of r35 could help to evaluate the reservoir physical properties intuitively and efficiently. The aim of the present study is to apply, pore throat radius (r35) concept (Winland equation) to discriminate reservoir flow units in cored wells side by side with application differences calculated between Neutron \& Density porosity curves to predict permeability in non-cored wells. The subdivision of Abu Madi reservoir rock into flow units by use of Neutron-Density curves was very helpful for permeability prediction in the non-cored wells.

\section{Methodology}

The workflow was started from Core data (Step-1) because it is the most accurate way for permeability determination. The Abu Madi reservoir rock was subdivided into flow units using pore throat radius (r35) concept [6] Equation (1):

$$
\mathrm{r} 35=2.665(K / \varnothing)^{0.45}
$$

Density and Neutron logs are porosity tools present in almost all the studied wells. Total porosity was estimated from Equation (2):

$$
\varnothing \mathrm{t}=(\varnothing \mathrm{N}+\varnothing \mathrm{D}) / 2
$$

The difference between Neutron and Density porosities indicates the quality of the sand reservoirs (in oil and wet gas reservoirs only as the dry gas has a direct effect on both density and neutron curves). The N-D porosity difference is a function of a certain reservoir flow unit. (Step-2)

A new log flow unit (LFU) was plotted along the reservoir thickness in all studied wells (cored and un-cored intervals) and correlated with the core flow units. The permeability was predicted for the reservoir section using complete log flow units (LFU) and the core permeability equation for each flow unit [1]. The predicted permeability was correlated with the core permeability against the core 
interval "Step-2, Figure 2".

The flow unit was determined from the Neutron-Density porosity relation and then permeability was predicted based on core flow unit equations. The wells production data (dynamic data) were used to checkup the predicted permeability in the un-cored wells. "Step-3, Figure 2".

\subsection{Log Data}

Four wells were selected for the present study (Baltim North-1, Baltim North-2, Baltim North $-5^{\text {th }}$ and Baltim NE-1). In these wells, GR, Resistivity, Density and Neutron logs are available. In wells BNE-1, BN-2 and BN-5 $5^{\text {th }}$ core data of the Abu Madi reservoir (Level III main) was available, but Baltim North-1 well was a logged but uncored well. Two cored wells Baltim North-2 and Baltim North- $5^{\text {th }}$ were used to generate permeability-porosity equations $\left(\mathrm{R}^{2}=65,60,48\right.$ and 72$)$ and they were tested against the core interval in Baltim NE-1 well and used to predict permeability in uncored well Baltim North-1.

\subsection{Available Core Data}

This study has been carried out using three cored wells, Baltim North-2, Baltim North $-5^{\text {th }}$ and Baltim NE-1. These cores coves level III Main.

\section{Core Sample Preparation}

\section{1) Core cutting}

One and half inch plugs were cut both parallel every $25 \mathrm{~cm}$ and perpendicular

\section{WORKFLOW}

\section{Step 1}

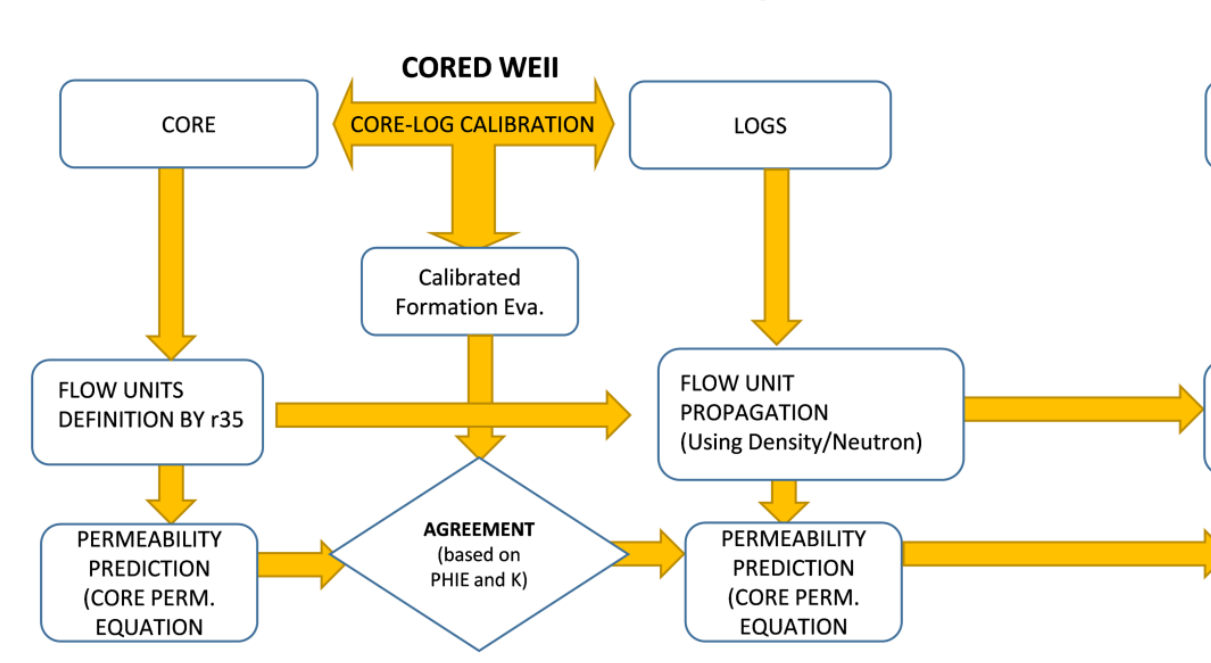

Step 3

LOGED WELL

LOGS

FLOW UNIT

PROPAGATION

(Using Density/Neutron)

PERMEABILITY PREDICTION FU dependent

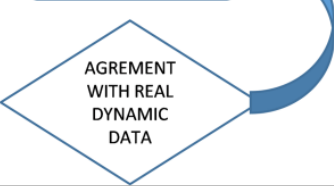

Figure 2. Workflow for core-log integration, flow unit's estimation from density-neutron and permeability prediction in the un-cored wells. 
to the core bedding every one meter through the core intervals. The plug samples were trimmed to produce right cylinders, and the trims labelled and boxed for subsequent use.

\section{2) Core cleaning and drying}

The plug samples were cleaned in hot refluxing solvents (Toluene and Methanol) and dried in a regular oven at $105 \mathrm{oC}$ [7]. Toluene is used to remove all hydrocarbons from the plug. The plug was hydrocarbon free when it has no fluorescence gold color under UV-light. Methanol is used to remove the salt from the plugs, the cleaning process was complete when silver nitrate (as indicator) does not react with the solvent (Methanol), which means that the solvent no longer has any salts. The porosity, permeability and density were measured by methods adopted by [8] [9].

\section{Results and Discussions}

\subsection{Flow Unit Concept}

Winland approach has been used for reservoir classification and flow prediction. Flow unit is defined as the characterization of the reservoir rock into units, which has uniform pore throat size distribution and similar flow performance. Flow Unit is the final product of the effect of digenetic processes [10] [11]. Pore throat radius (r35) is calculated according to the Winland Equation (3) [12]:

$$
\log \mathrm{r} 35=0.732+0.588 \log k-0.864 \log \mathrm{phi}
$$

Martine et al. (1997) [13] used r35 to identify four reservoir flow units:

1) mega-port flow unit, where $\mathrm{r} 35$ is higher than $10 \mu \mathrm{m}$ (FU4);

2) macro-port flow unit where $\mathrm{r} 35$ ranging between 2 and $10 \mu \mathrm{m}$ (FU3);

3) meso-port-flow unit whose $\mathrm{r} 35$ is between 0.5 and $2 \mu \mathrm{m}$ (FU2);

4) micro-port flow unit that has $\mathrm{r} 35$ less than $0.5 \mu \mathrm{m}$ (FU1).

\subsection{Reservoir Flow Units}

Based on the r35 (Winland equation), the Baltim reservoir (level III main) in Baltim North $-5^{\text {th }}$ well was subdivided into three flow units against depth. Flow units FU4, FU3 and FU2 (Table 1 \& Figure 3). Each FU has uniform pore throat size distribution and similar flow performance regarding its position in the well or in the field (Table 2).

In well Baltim North-2 the reservoir (level III main) was subdivided into four flow units against depth FU4, FU3, FU2 and FU1 (Table 3 \& Figure 4).

Each FU has uniform pore throat size distribution and similar flow performance regarding its position in the well or in the field (Table 4).

\subsection{Porosity-Permeability Relationships}

The porosity and permeability from two cored wells (Baltim North $-5^{\text {th }}$ and Baltim North-2) was discriminated based on the flow units. The core porosity was plotted versus core permeability for each flow unit in the two wells and the relation was established (Figure 5). 
Table 1. Using Winland equation for $\mathrm{r} 35$ calculation in the Baltim North- $5^{\text {st }}$ well.

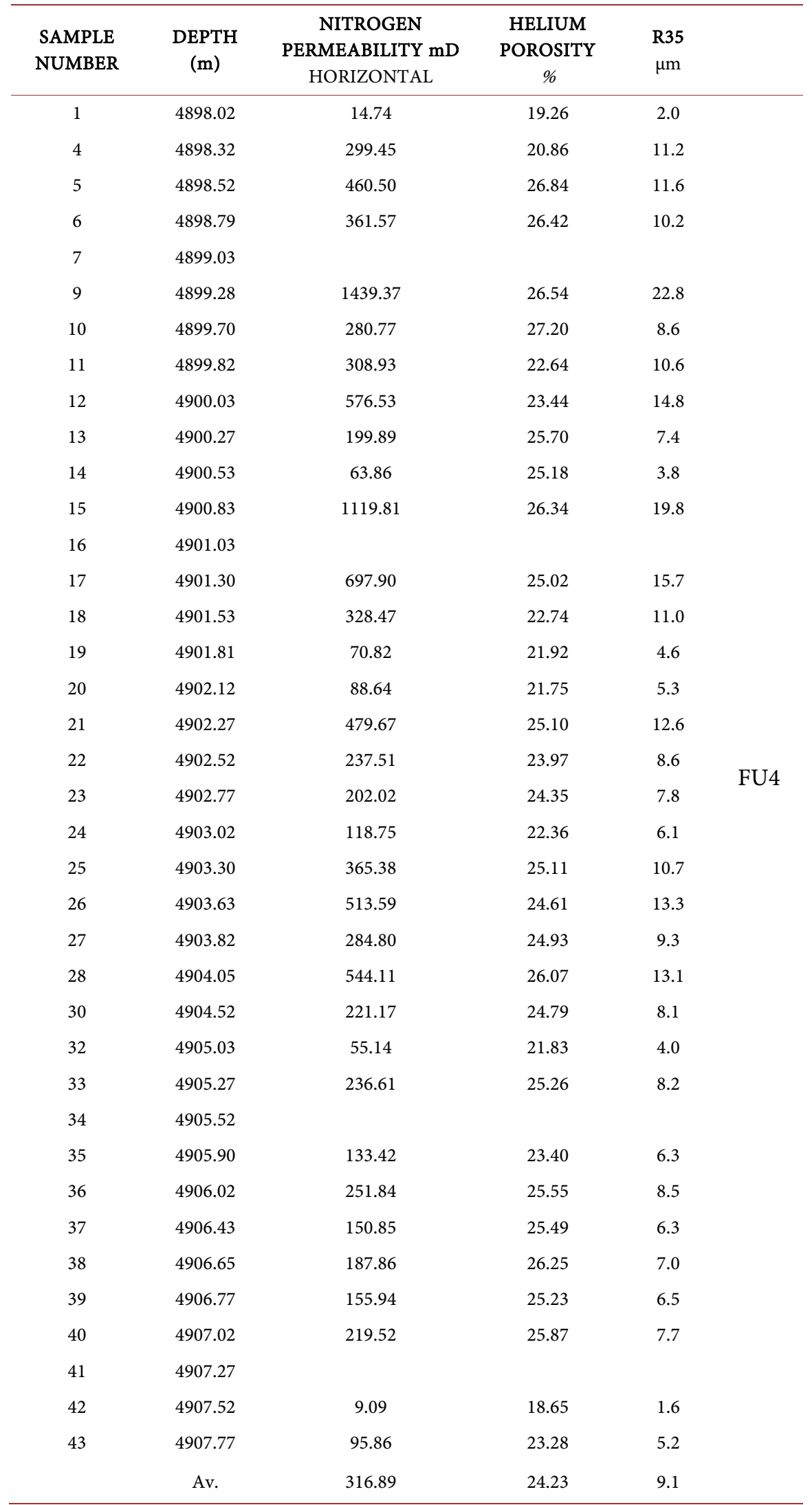




\section{Continued}

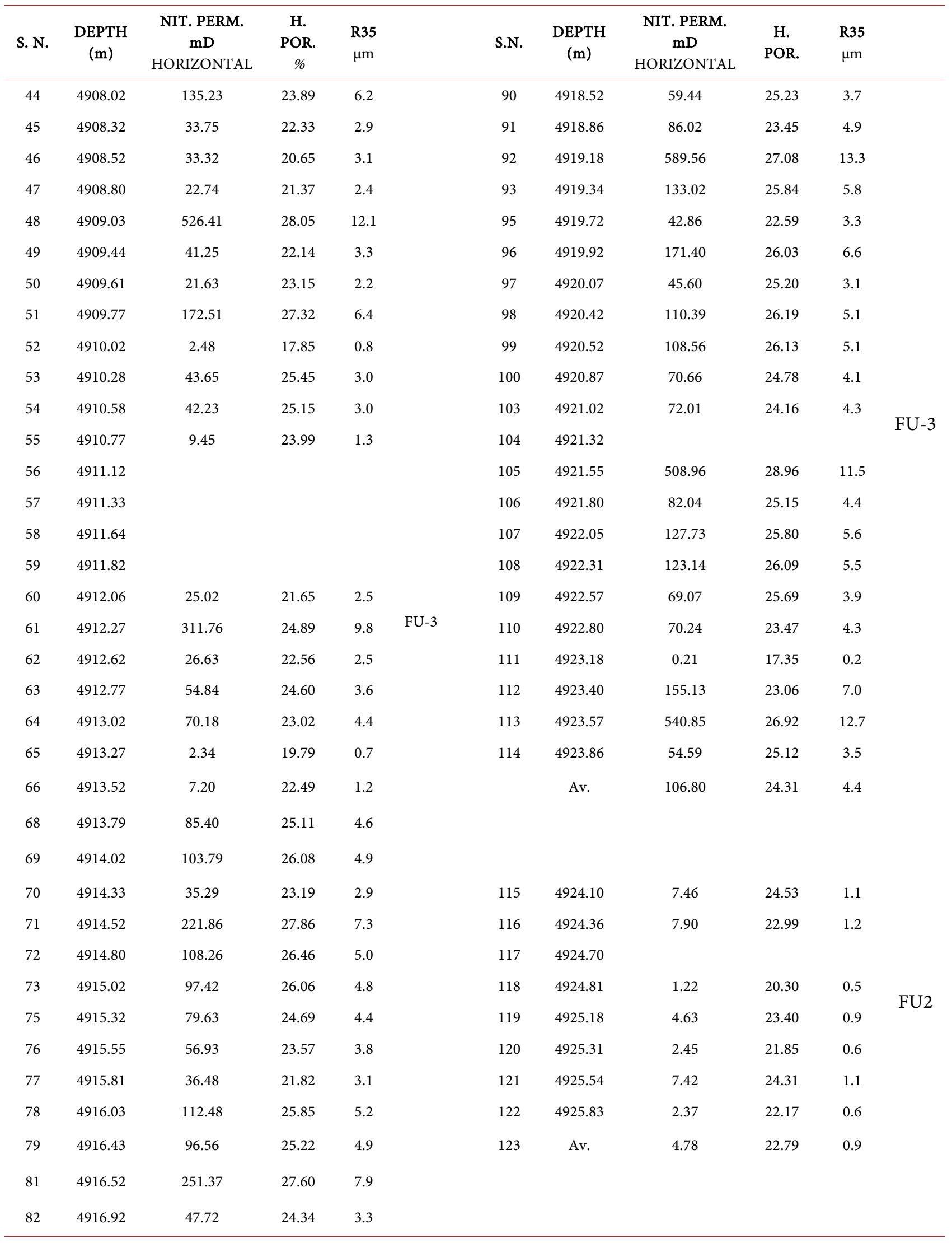


A. M. A. El Sayed et al.

\section{Continued}

\begin{tabular}{lllll}
\hline 84 & 4917.03 & 16.98 & 23.49 & 1.9 \\
85 & 4917.26 & 51.75 & 25.76 & 3.3 \\
86 & 4917.54 & 30.26 & 24.79 & 2.5 \\
87 & 4917.92 & 82.82 & 25.75 & 4.4 \\
88 & 4918.17 & 339.12 & 27.15 & 9.6 \\
89 & 4918.28 & 621.82 & 28.59 & 13.1 \\
\hline
\end{tabular}

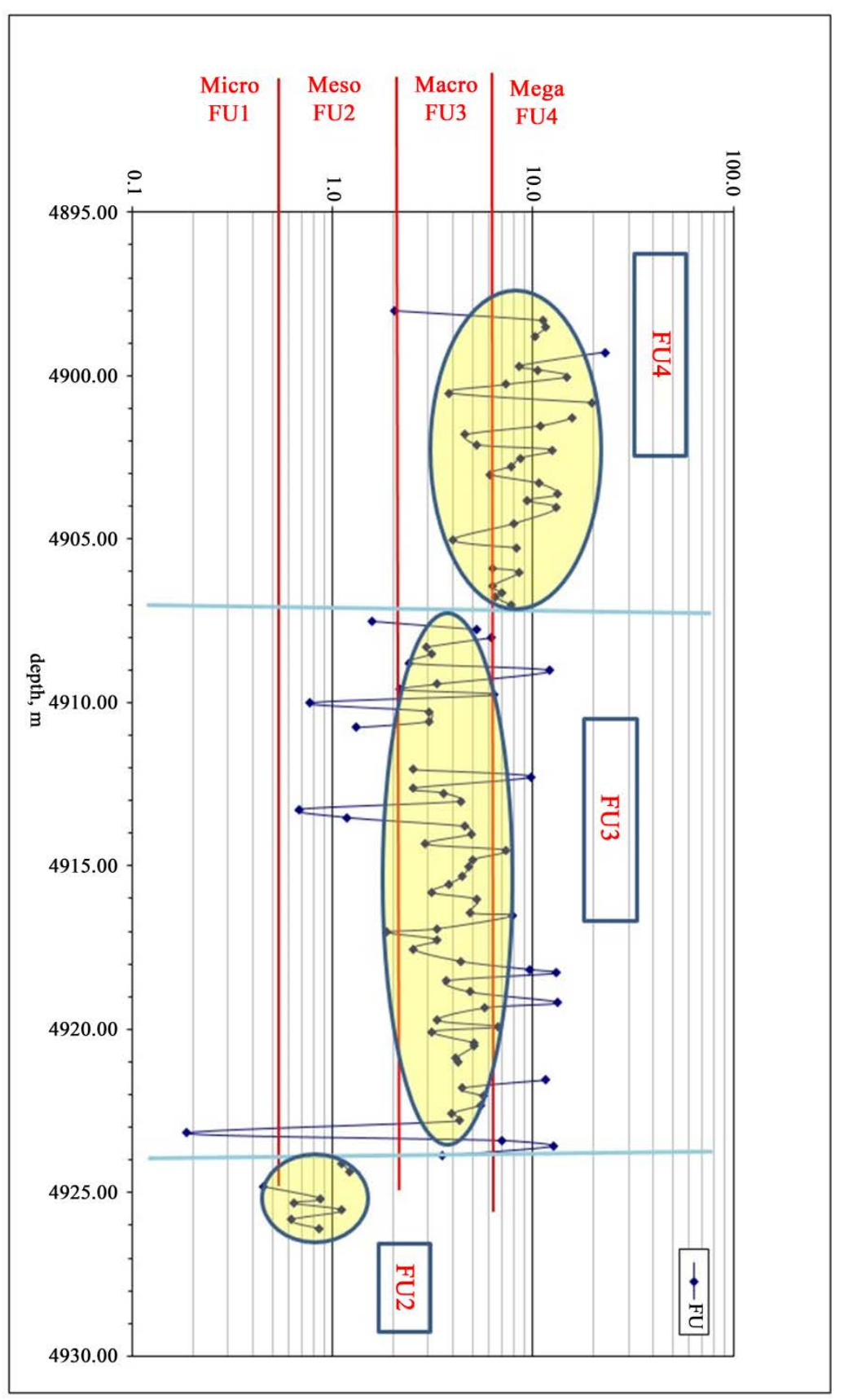

Figure 3. Flow unit's identification in cored well Baltim North $-5^{\text {th }}$. 
Table 2. Average reservoir parameters for flow units in Level III Main in well Baltim North- $5^{\text {th }}$.

\begin{tabular}{|c|c|c|c|c|c|c|}
\hline FU & $\begin{array}{l}\text { INTERVAL } \\
\text { DEPTH (m) }\end{array}$ & $\begin{array}{l}\text { R35 } \\
\text { Лm }\end{array}$ & $\begin{array}{c}\text { POROSITY } \\
\%\end{array}$ & $\begin{array}{c}\text { Horizontal } \\
\text { Permeability md }\end{array}$ & $\begin{array}{l}\text { Vertical Permeability } \\
\text { md }\end{array}$ & $\begin{array}{c}\text { Grain Density } \\
\text { gm/cc }\end{array}$ \\
\hline FU4 & $4898.02-4907.77$ & 9.1 & 24 & 308 & 172 & 2.68 \\
\hline FU3 & $4908.02-4923.86$ & 4.8 & 25 & 123 & 56 & 2.69 \\
\hline FU2 & $4924.10-4925.83$ & 0.9 & 23 & 5 & 2 & 2.71 \\
\hline
\end{tabular}

Table 3. Using Winland equation for $\mathrm{r} 35$ calculation in Baltim North-2 well.

\begin{tabular}{|c|c|c|c|c|c|c|c|c|c|c|c|}
\hline S.N. & $\begin{array}{c}\text { DEPTH } \\
(\mathrm{m})\end{array}$ & $\begin{array}{c}\text { NITR. PERM. } \\
\text { mD } \\
\text { HORIZ. }\end{array}$ & $\begin{array}{c}\text { HEL. POR. } \\
\%\end{array}$ & $\begin{array}{l}\mathrm{R} 35 \\
\mu \mathrm{m}\end{array}$ & & S.N. & $\begin{array}{c}\text { DEPTH } \\
(\mathrm{m})\end{array}$ & $\begin{array}{c}\text { NITR. PERM. } \\
\text { mD } \\
\text { HORIZ. }\end{array}$ & $\begin{array}{c}\text { HEL. POR. } \\
\%\end{array}$ & $\begin{array}{l}\mathrm{R} 35 \\
\mu \mathrm{m}\end{array}$ & \\
\hline 1 & 3704.00 & & & & & 53 & 3719.60 & 131.00 & 22.90 & 6.3 & \\
\hline 2 & 3704.30 & & & & & 54 & 3719.90 & 179.00 & 22.90 & 7.6 & \\
\hline 3 & 3704.60 & 1.64 & 16.00 & 0.7 & & 55 & 3720.20 & 6.90 & 14.10 & 1.7 & \\
\hline 4 & 3704.90 & 9.90 & 21.60 & 1.5 & & 56 & 3720.50 & & & & \\
\hline 5 & 3705.20 & & & & & 57 & 3720.80 & 783.00 & 26.80 & 15.8 & \\
\hline 6 & & & & & & 58 & 3721.10 & 111.00 & 23.30 & 5.7 & \\
\hline 7 & 3705.80 & 3.25 & 19.60 & 0.8 & & 59 & 3721.40 & 93.90 & 22.00 & 5.4 & \\
\hline 8 & 3706.10 & 4.21 & 22.90 & 0.8 & & 60 & 3721.70 & 169.00 & 22.90 & 7.4 & FU-4 \\
\hline 9 & 3706.40 & 3.43 & 23.50 & 0.7 & & 61 & 3722.00 & 349.00 & 24.30 & 10.7 & \\
\hline 10 & 3706.70 & 1.26 & 19.20 & 0.5 & & 62 & 3722.30 & 314.00 & 24.70 & 9.9 & \\
\hline 11 & 3707.00 & 4.64 & 20.80 & 1.0 & & 63 & 3722.60 & 70.00 & 22.60 & 4.4 & \\
\hline 12 & 3707.30 & 3.78 & 19.60 & 0.9 & & 64 & 3722.90 & 358.00 & 25.10 & 10.6 & \\
\hline 13 & 3707.60 & 7.49 & 21.80 & 1.2 & & 65 & 3723.20 & 771.00 & 26.10 & 16.1 & \\
\hline 14 & 3707.90 & 8.89 & 22.80 & 1.3 & FU-2 & 66 & 3723.50 & & & & \\
\hline 15 & 3708.20 & 18.80 & 20.80 & 2.2 & & 67 & 3723.80 & 602.00 & 26.90 & 13.5 & \\
\hline 16 & 3708.50 & 0.57 & 12.70 & 0.4 & & 68 & 3724.10 & 302.91 & 23.43 & 8.9 & \\
\hline 17 & 3708.80 & 2.95 & 17.40 & 0.9 & & 69 & 3724.40 & & & & \\
\hline 18 & 3709.10 & 0.76 & 15.80 & 0.4 & & 70 & 3724.70 & & & & \\
\hline 19 & 3709.40 & 17.40 & 22.10 & 2.0 & & 71 & 3725.00 & & & & \\
\hline 20 & & & & & & 72 & 3725.30 & 0.17 & 10.10 & 0.3 & \\
\hline 21 & 3710.00 & 5.94 & 21.40 & 1.1 & & 73 & 3725.60 & 0.98 & 17.20 & 0.5 & \\
\hline 22 & 3710.30 & & & & & 74 & 3725.90 & 1.14 & 19.30 & 0.5 & \\
\hline 23 & 3710.60 & 12.10 & 21.40 & 1.7 & & 75 & 3726.20 & 0.76 & 12.00 & 0.5 & \\
\hline 24 & 3710.90 & 23.00 & 23.50 & 2.2 & & 76 & 3726.50 & 0.10 & 12.80 & 0.2 & FU-1 \\
\hline 25 & 3711.20 & 7.35 & 21.70 & 1.2 & & 77 & 3726.80 & 0.17 & 11.90 & 0.2 & \\
\hline \multirow[t]{3}{*}{26} & 3711.50 & 4.08 & 21.80 & 0.9 & & 78 & 3727.10 & 0.08 & 11.60 & 0.1 & \\
\hline & Av. & 7.07 & 20.32 & 1.1 & & 79 & 3727.40 & & & & \\
\hline & & & & & & 80 & 3727.70 & & & & \\
\hline
\end{tabular}




\section{Continued}

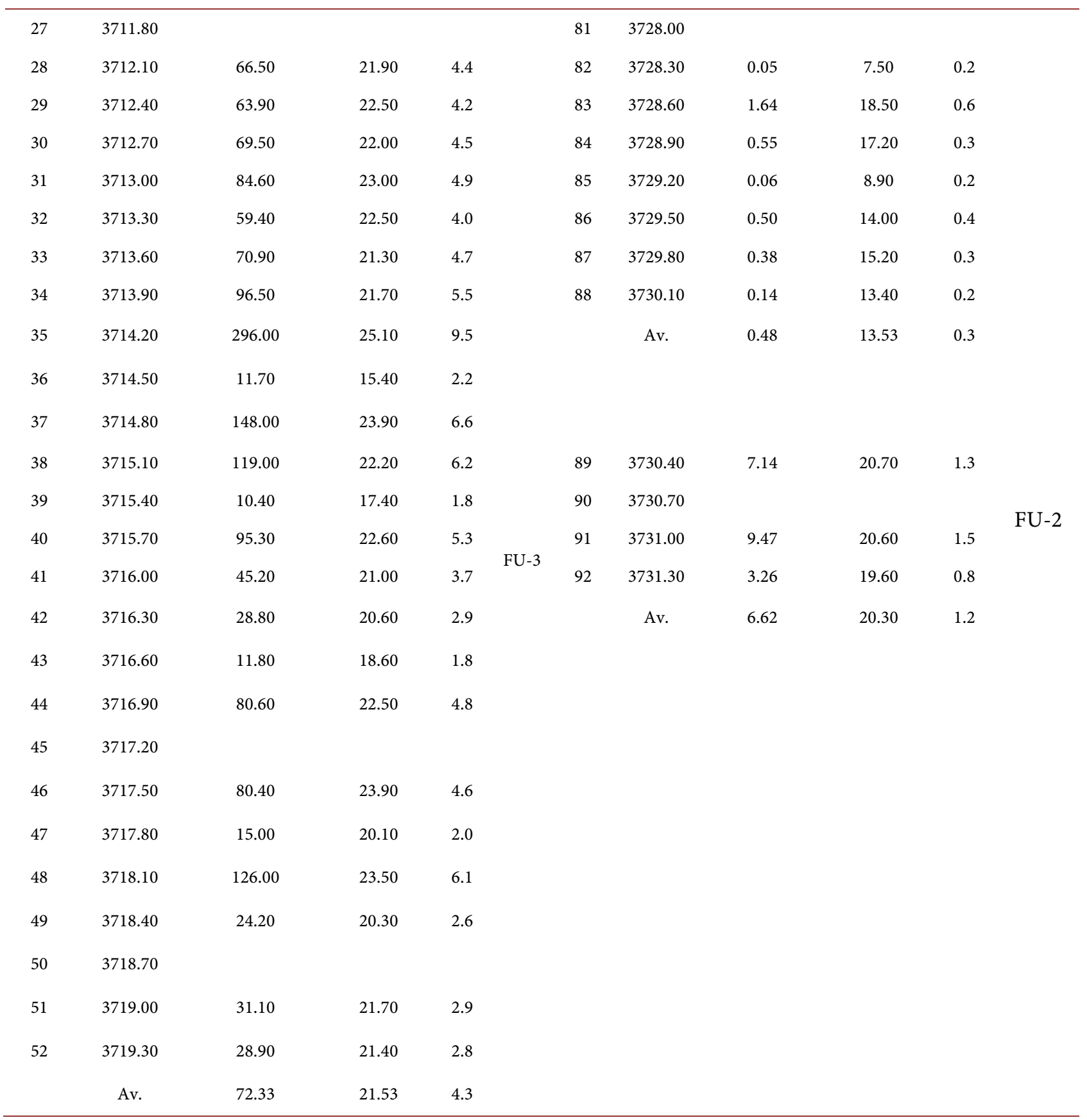

Permeability was estimated for FU4 from Equation (4):

$$
K=5 \mathrm{E}-09 * \emptyset^{7.713}
$$

Permeability was estimated for FU3 from Equation (5):

$$
K=4 \mathrm{E}-10 * \emptyset^{8.183}
$$

Permeability was estimated for FU2 from Equation (6):

$$
K=6 \mathrm{E}-06 * \varnothing^{4.4625}
$$

Permeability was estimated for FU1 from Equation (7): 


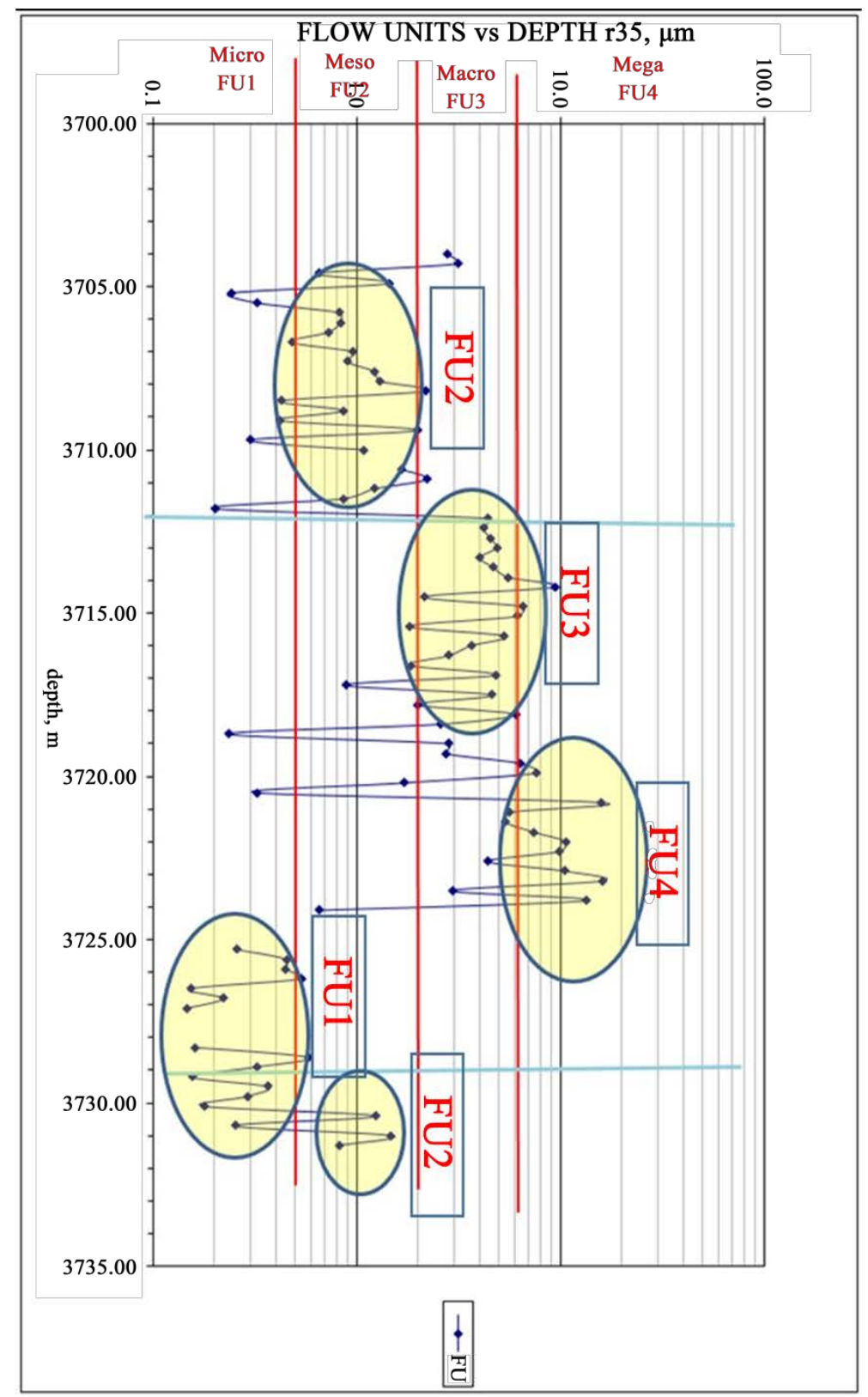

Figure 4. Flow unit's identification in cored well Baltim North-2 (Level III Main).

Table 4. Average reservoir parameters for flow units in Level III main in Baltim North-2 well.

\begin{tabular}{ccccccc}
\hline FU & $\begin{array}{c}\text { INTERVAL } \\
\text { DEPTH (m) }\end{array}$ & $\begin{array}{c}\text { R35 } \\
\text { micro } \\
\text { meter }\end{array}$ & $\begin{array}{c}\text { POROSITY } \\
\%\end{array}$ & $\begin{array}{c}\text { Horizontal } \\
\text { Permeability } \\
\text { md }\end{array}$ & $\begin{array}{c}\text { Vertical } \\
\text { Permeability } \\
\text { md }\end{array}$ & $\begin{array}{c}\text { Grain } \\
\text { Density } \\
\text { gm/cc }\end{array}$ \\
\hline FU2 & $3704.6-3711.5$ & 1.1 & 20.3 & 7.1 & 1.5 & 2.69 \\
FU3 & $3712.1-3719.3$ & 4.3 & 21.5 & 72 & 16 & 2.68 \\
FU4 & $3719.6-3723.8$ & 8.9 & 23.4 & 303 & 70 & 2.68 \\
FU1 & $3725.3-3730.1$ & 0.3 & 13.5 & 0.48 & 0 & 2.72 \\
FU2 & $3730.4-3731.3$ & 1.2 & 20.3 & 6.6 & 1.7 & 2.71 \\
\hline
\end{tabular}




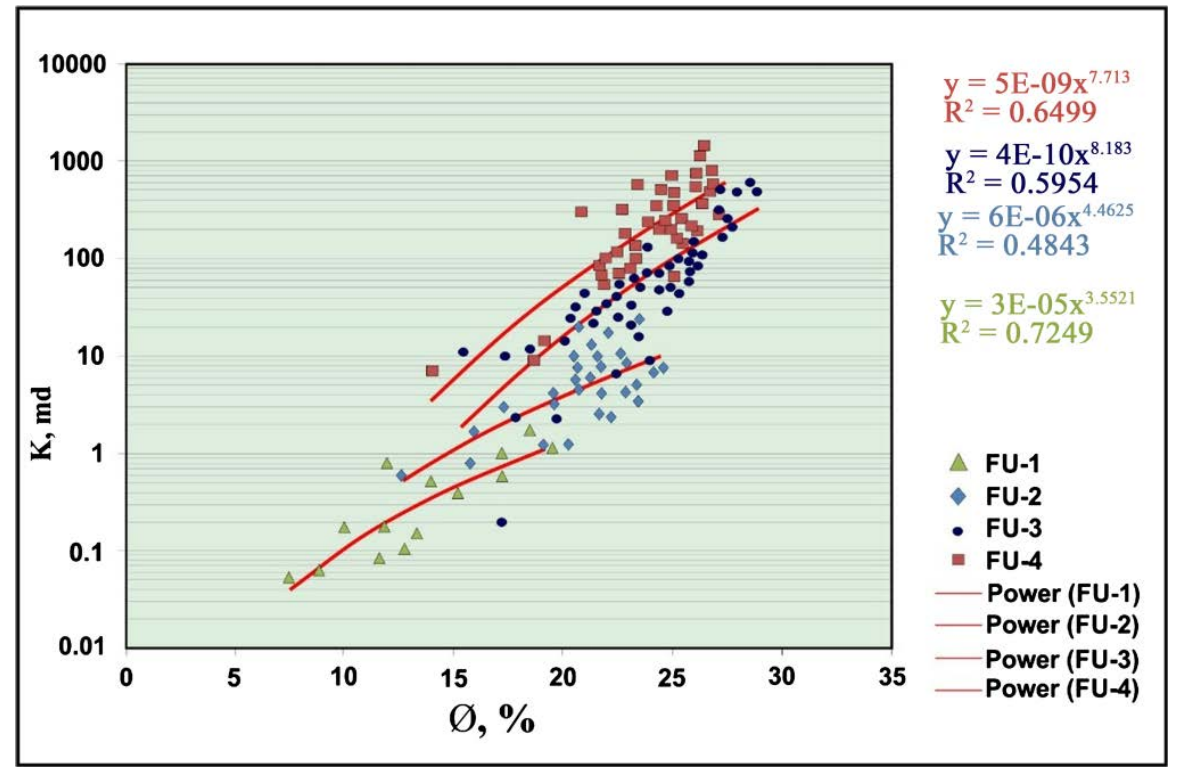

Figure 5. Porosity-Permeability relation using flow units in cored wells Baltim North- $5^{\text {th }}$ and Baltim North-2 (Level III Main).

$$
K=3 \mathrm{E}-05 * \varnothing^{3.5521}
$$

Permeability was predicted (Synthetic curve) for the two cored wells (Baltim North $-5^{\text {th }}$ and Baltim North-2) against the core intervals from the previous equations and the result is in a good match with the core permeability (Figure 6 and Figure 7).

\subsection{Core-Log Integration}

Permeability prediction is still a great challenge in uncored wells. Flow units (FU) is the concept to relate permeability to porosity in cored wells, but the main challenge is how to define flow units in uncored wells. Generally, in case of oil or wet gas sand reservoirs, the separation between Density -Neutron curves reflect the quality of the sand. From the correlation between Flow Units and Density-Neutron logs in the cored well Baltim North- $5^{\text {th }}$, the FU4 (which characterized by high porosity and high permeability) was correlate with the high Density-Neutron separation and the FU1 was correlate with the small separation (Figure 8).

Based on this observation, Flow unit can be estimated (EFU) from the relation between porosity determined from petrophysical evaluation $(\varnothing)$ and the difference calculated from Neutron porosity and Density porosity (Ø_N - Ø_D) in the two cored wells (Baltim North- $5^{\text {th }}$ and Baltim North-2). Indications for separation between Density and Neutron using flow units are shown in Figure 9 and Figure 10.

EFU4 was defined from the Equation (8):

$$
\text { EFU4 }=(\varnothing \mathrm{N}-\varnothing \mathrm{D})<0.002
$$

FUE3 was defined from the Equation (9): 


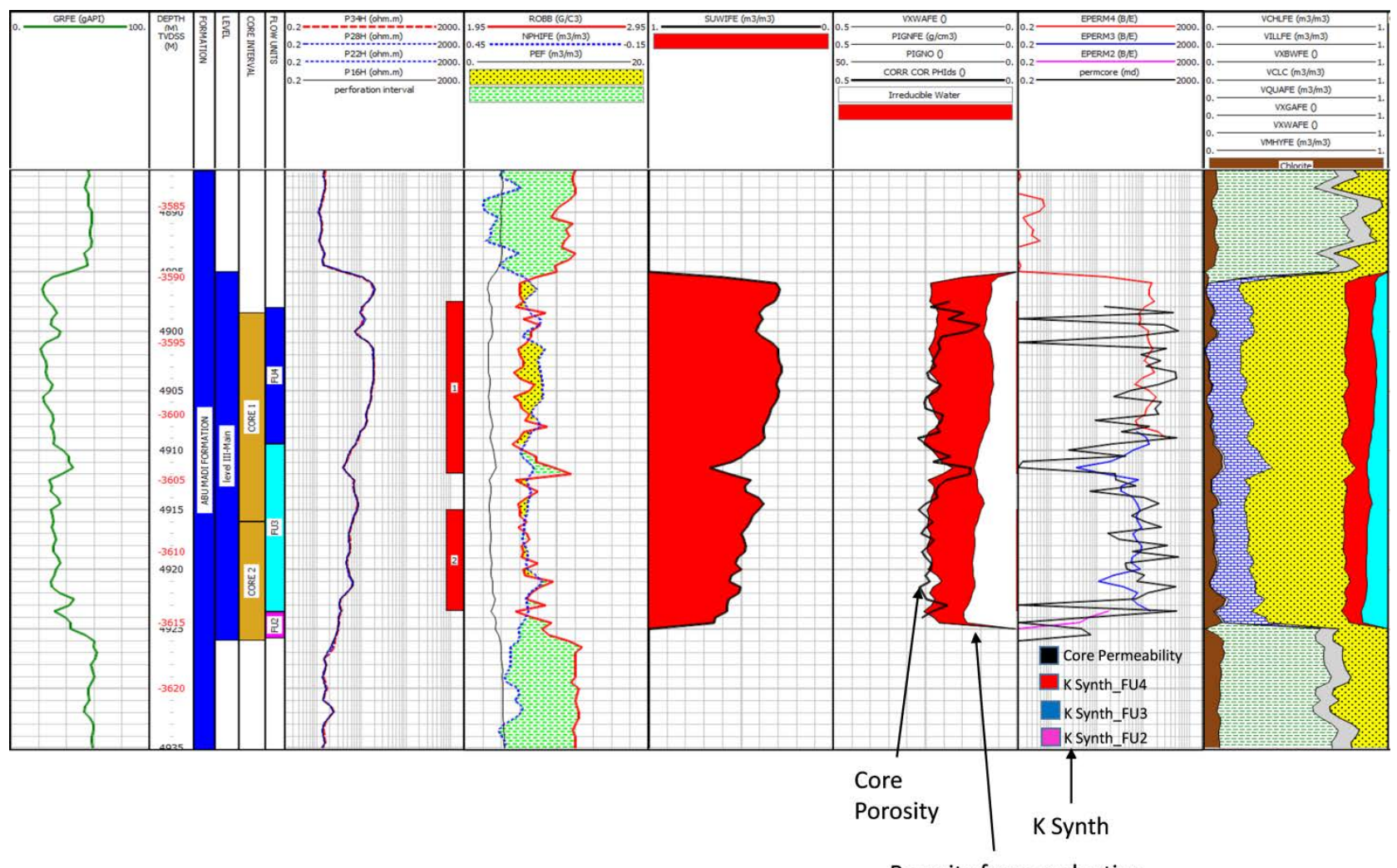

Porosity from evaluation

Figure 6. Permeability prediction (Synth.) in the cored well Baltim North- $5^{\text {th }}$.

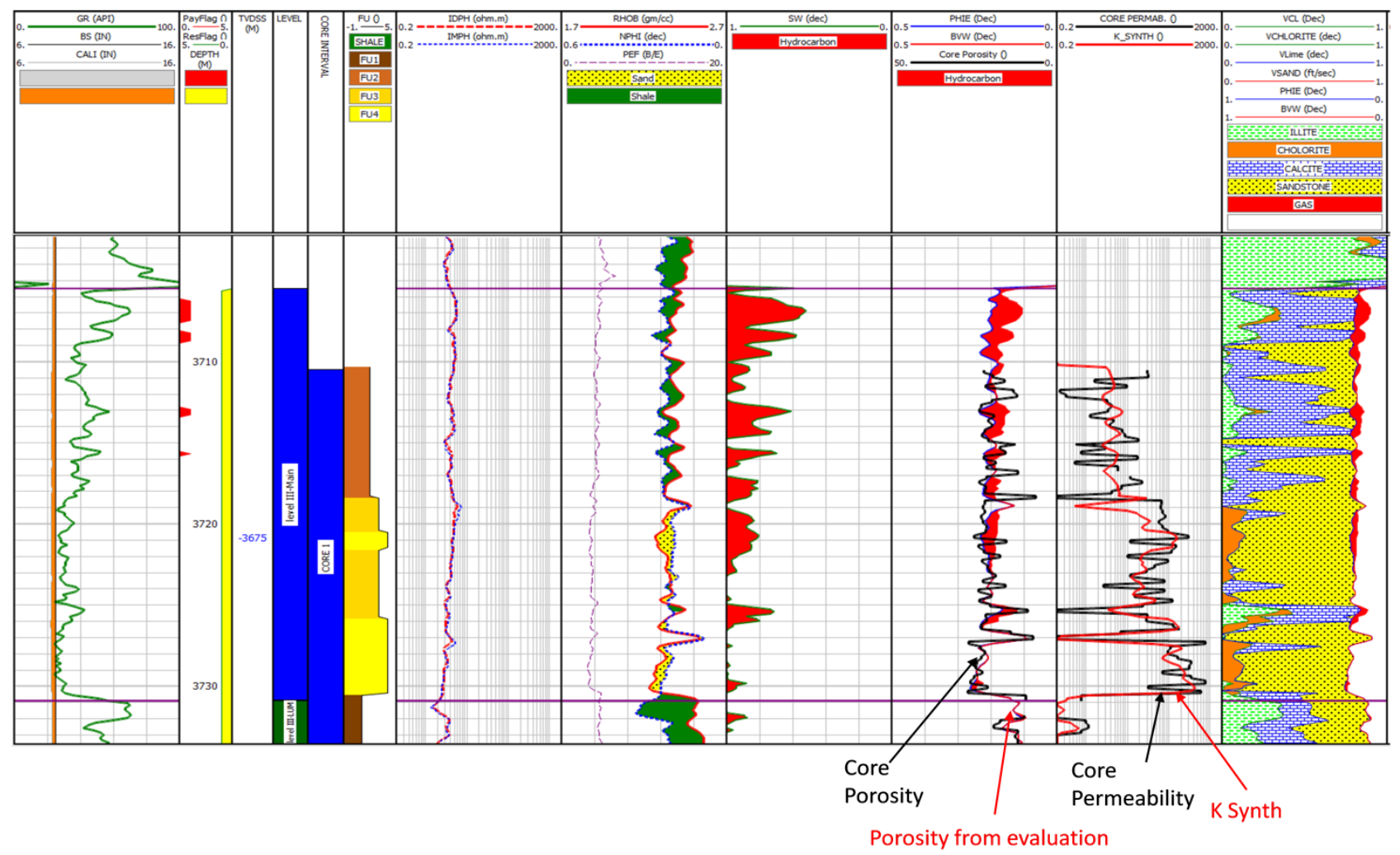

Figure 7. Permeability prediction (Synth.) in the cored well Baltim North-2. 


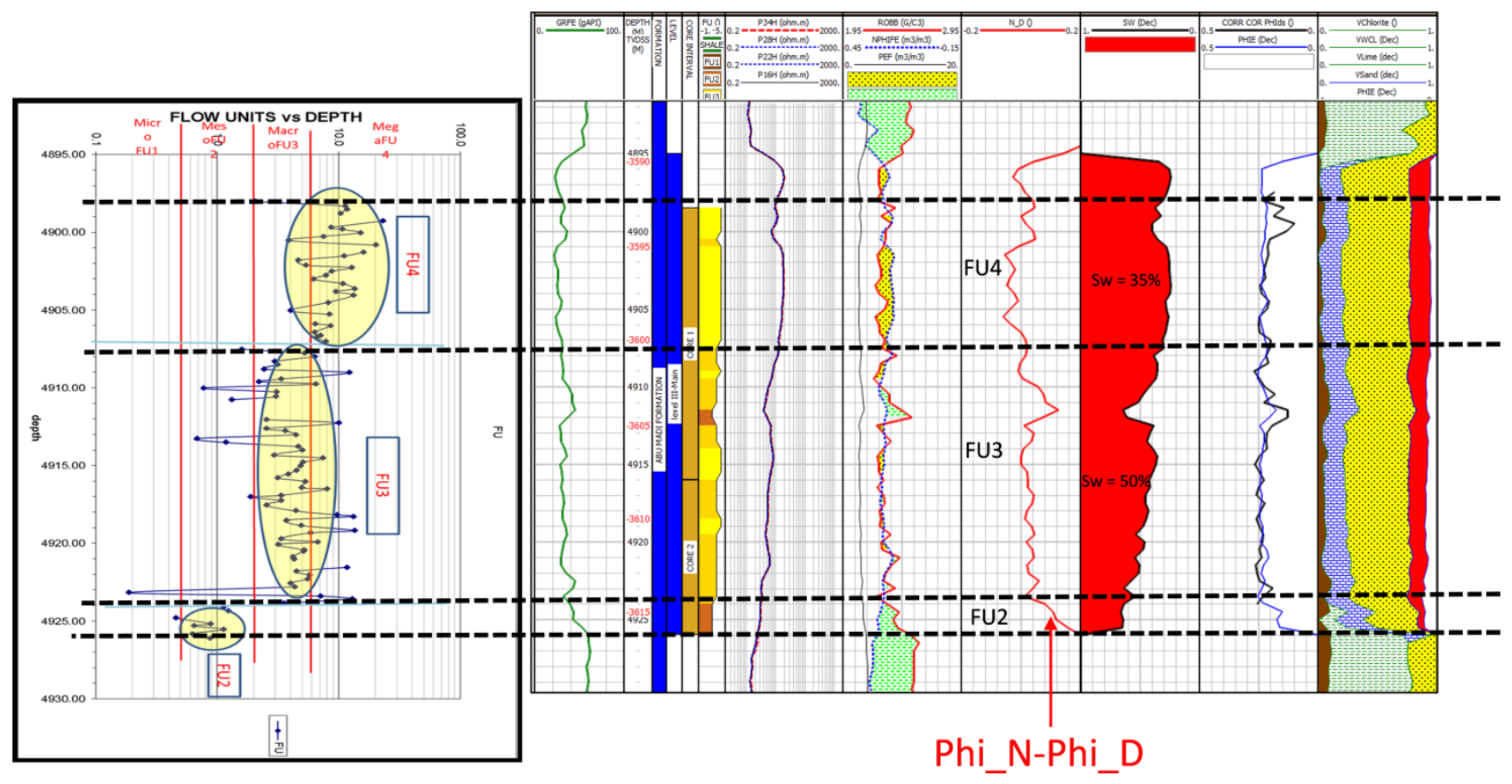

Figure 8. Correlation between FU and density-neutron porosity in the cored well Baltim North- $5^{\text {th }}$.

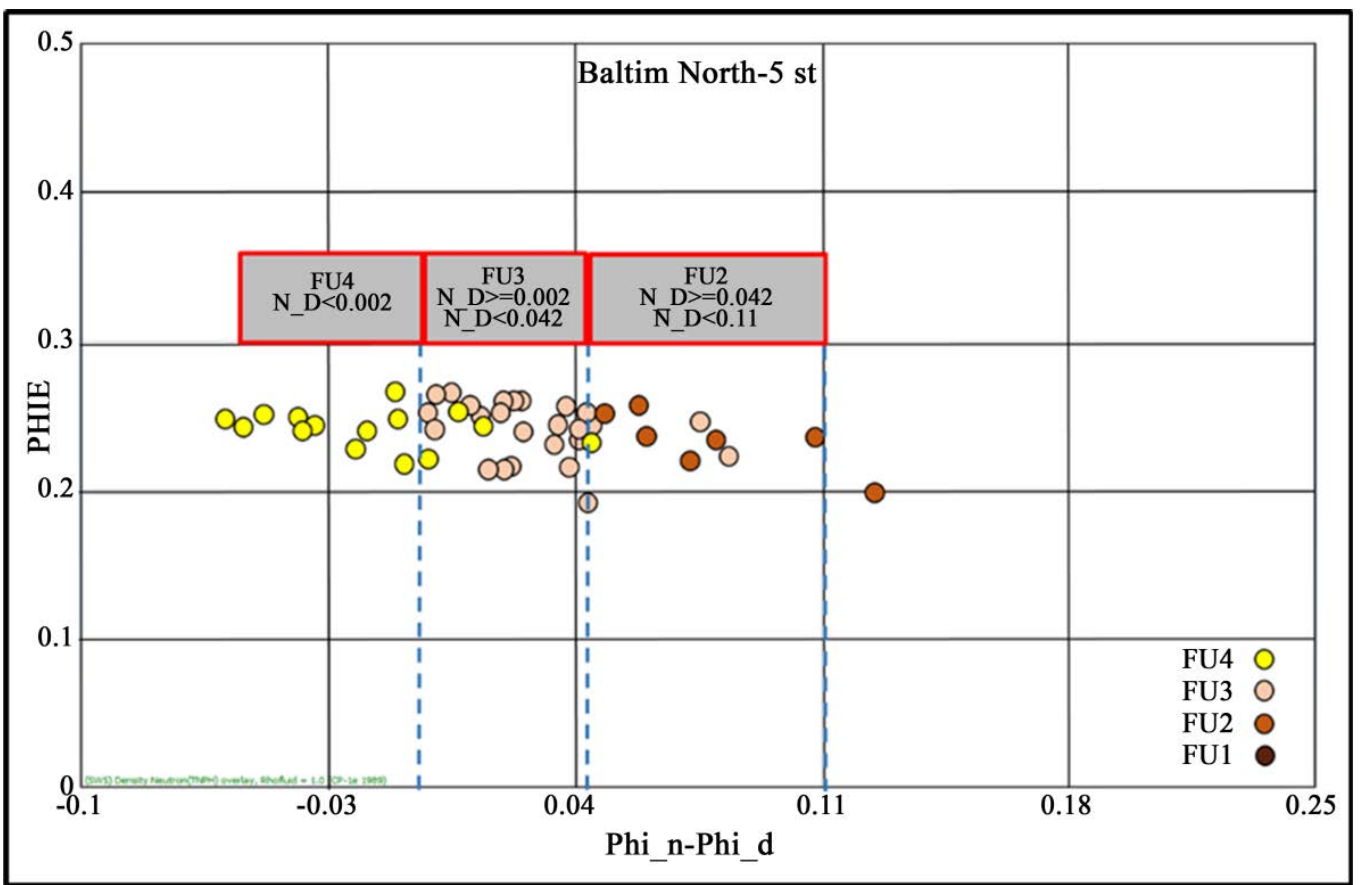

Figure 9. FU estimation from the relation between $\varnothing$ core and the difference between $\varnothing$-Neutron and $\varnothing$-Density (from logs), well Baltim North- $5^{\text {th }}$.

$$
\mathrm{EFU} 3=(\varnothing \mathrm{N}-\varnothing \mathrm{D}) \geq 0.002,(\varnothing \mathrm{N}-\varnothing \mathrm{D})<0.042
$$

FUE2 was defined from the Equation (10):

$$
\text { EFU2 }=(\varnothing \mathrm{N}-\varnothing \mathrm{D}) \geq 0.042,(\varnothing \mathrm{N}-\varnothing \mathrm{D})<0.11
$$

FUE1 was defined from the Equation (11): 


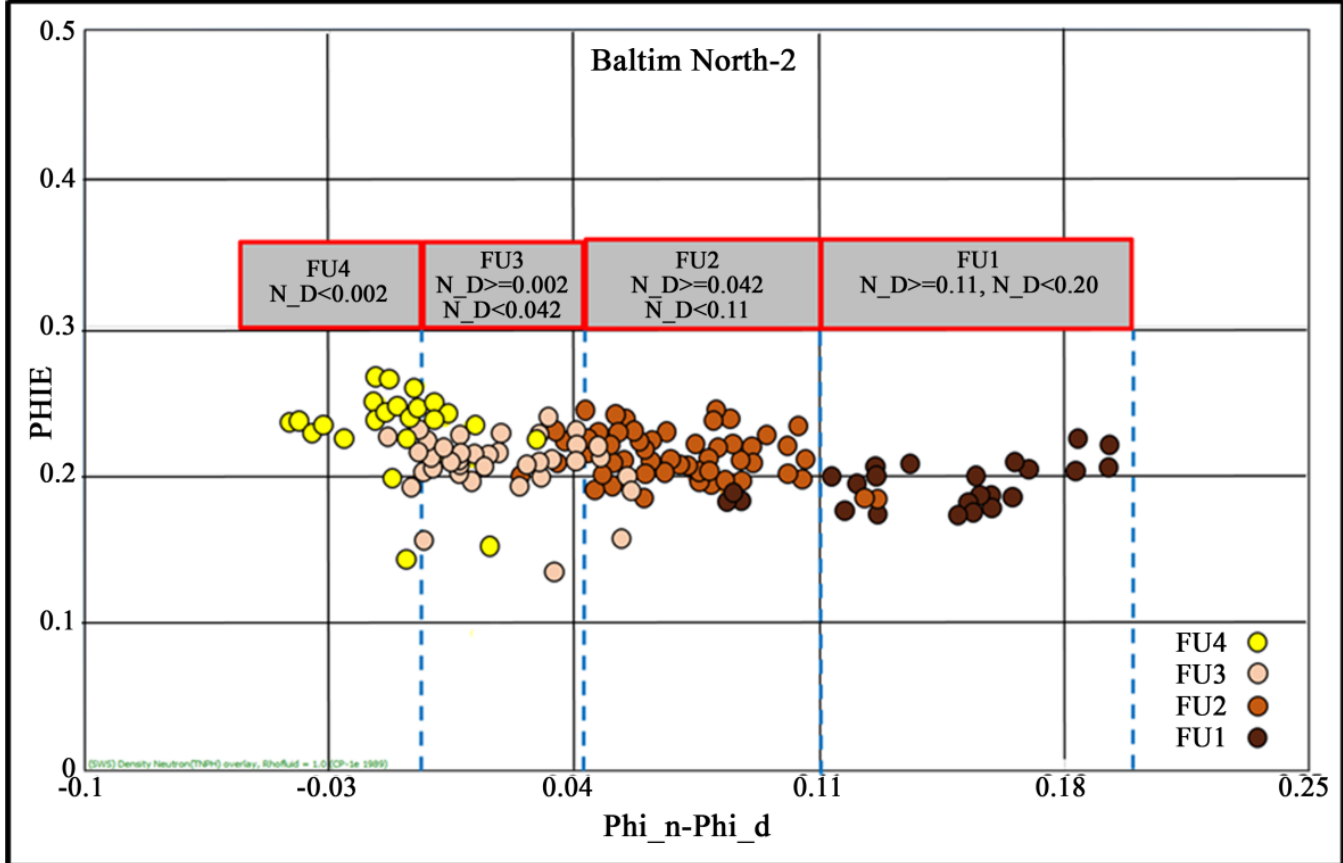

Figure 10. FU estimation from the relation between $\varnothing$ core and the difference between $\varnothing_{-}$Neutron and $\varnothing_{-}$Density (from logs), well Baltim North-2.

$$
\mathrm{EFU} 1=(\varnothing \mathrm{N}-\varnothing \mathrm{D}) \geq 0.011,(\varnothing \mathrm{N}-\varnothing \mathrm{D})<0.20
$$

\subsection{Permeability Prediction in Non-Cored Wells}

Flow units have been determined from the difference between Neutron porosity and Density porosity and after that, the permeability was estimated from Equations (4)-(7) which used for permeability prediction in uncored wells by putting $\log$ porosity instead of core one.

\subsubsection{Verification of the Used Techniques}

The present technique was applied to estimate permeability in cored wells to be tested by the already laboratory measured from core data and the results were presented in Figures 11-14.

\subsubsection{Reservoir Production Behavior, Flow Unit, and Permeability Prediction}

The production behavior is very important to confirm the validation of FU estimation and permeability prediction using the Density/Neutron porosity technique. The estimated FU from $\mathrm{D} / \mathrm{N}$ porosity technique for the perforated reservoir interval in well Baltim North-1 showing that most of this interval is related to FU2 while in well Baltim North- $5^{\text {th }}$ was related to FU4. The estimated average permeability value in well Baltim North-1 was $9.0 \mathrm{mD}$ while in well Baltim North $-5^{\text {th }}$ was $58.0 \mathrm{mD}$ which indicate that oil production from Baltim North- $5^{\text {th }}$ higher than that from Baltim North-1. The actual production from un- cored well Baltim North-1 is lower than that from the cored well Baltim North- $5^{\text {th }}$ (Figure 15). 


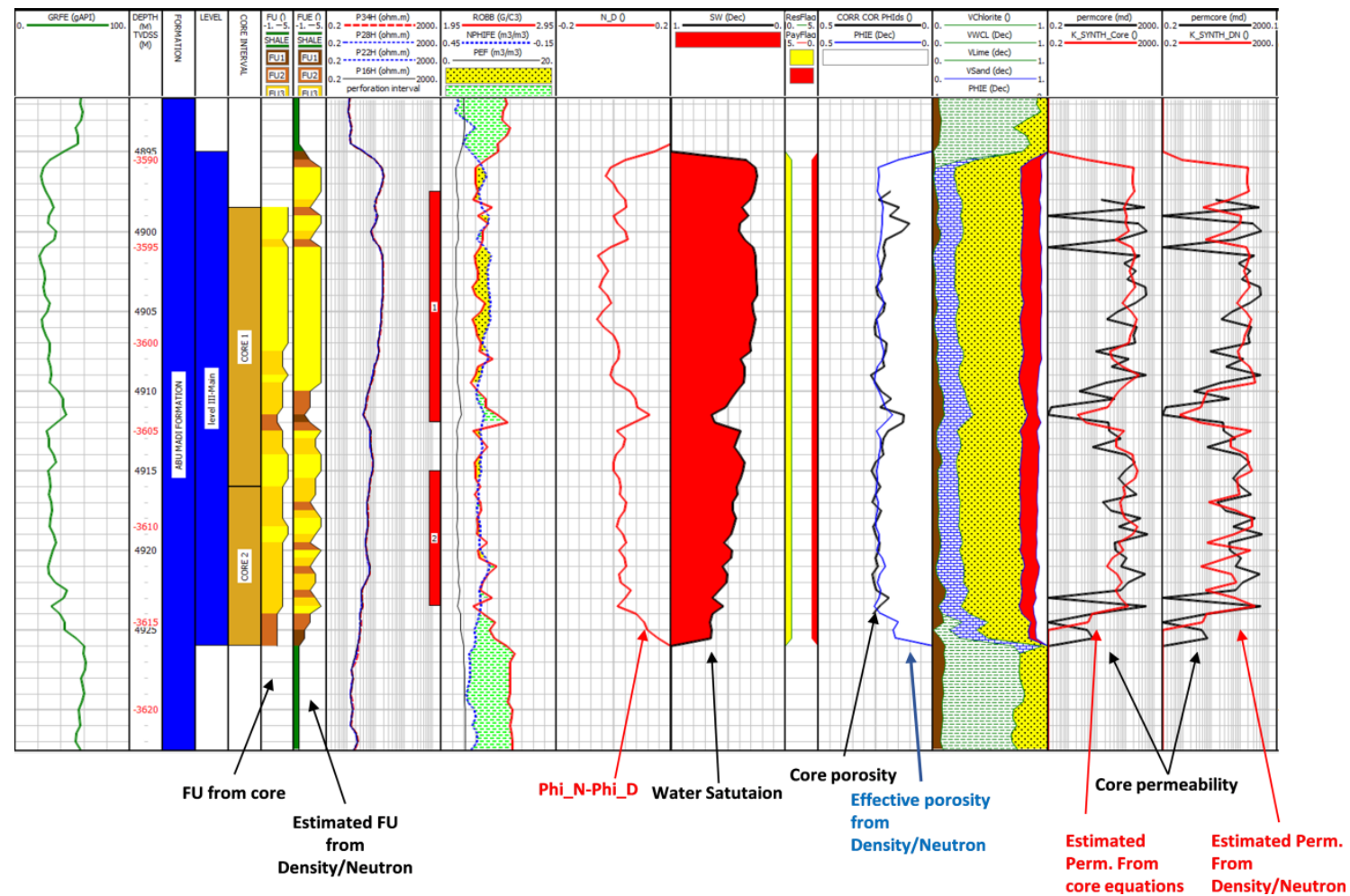

Figure 11. Comparison between Estimated FU and predicted permeability from Density-Neutron technique used and lab. Core data in well Baltim North- $5^{\text {th }}$.

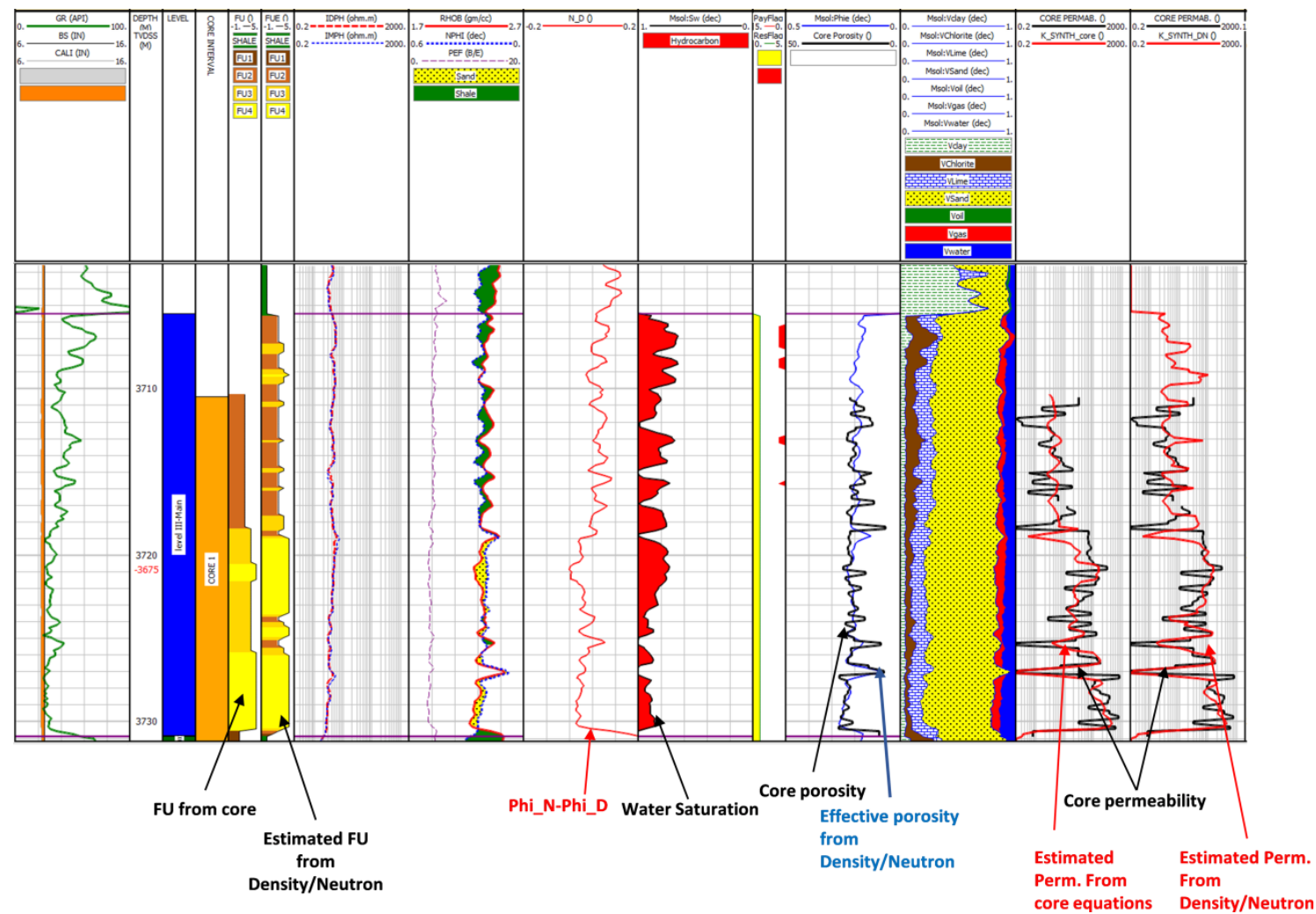

Figure 12. Comparison between Estimated FU and predicted permeability from Density-Neutron technique and laboratory core data in well Baltim North-2. 


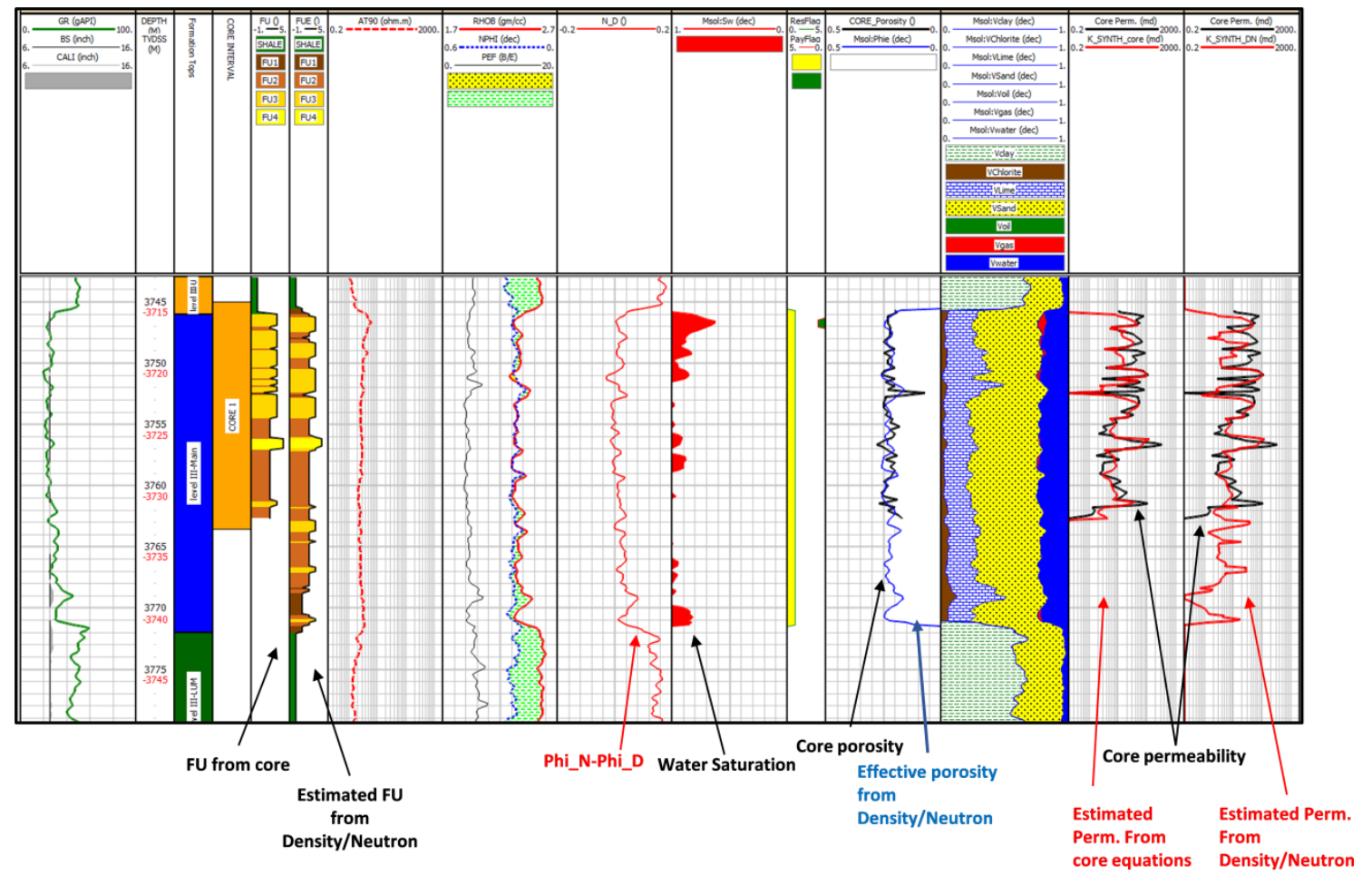

Figure 13. Comparison between Estimated FU and predicted permeability from Density-Neutron technique used and core data in well Baltim North East-1.

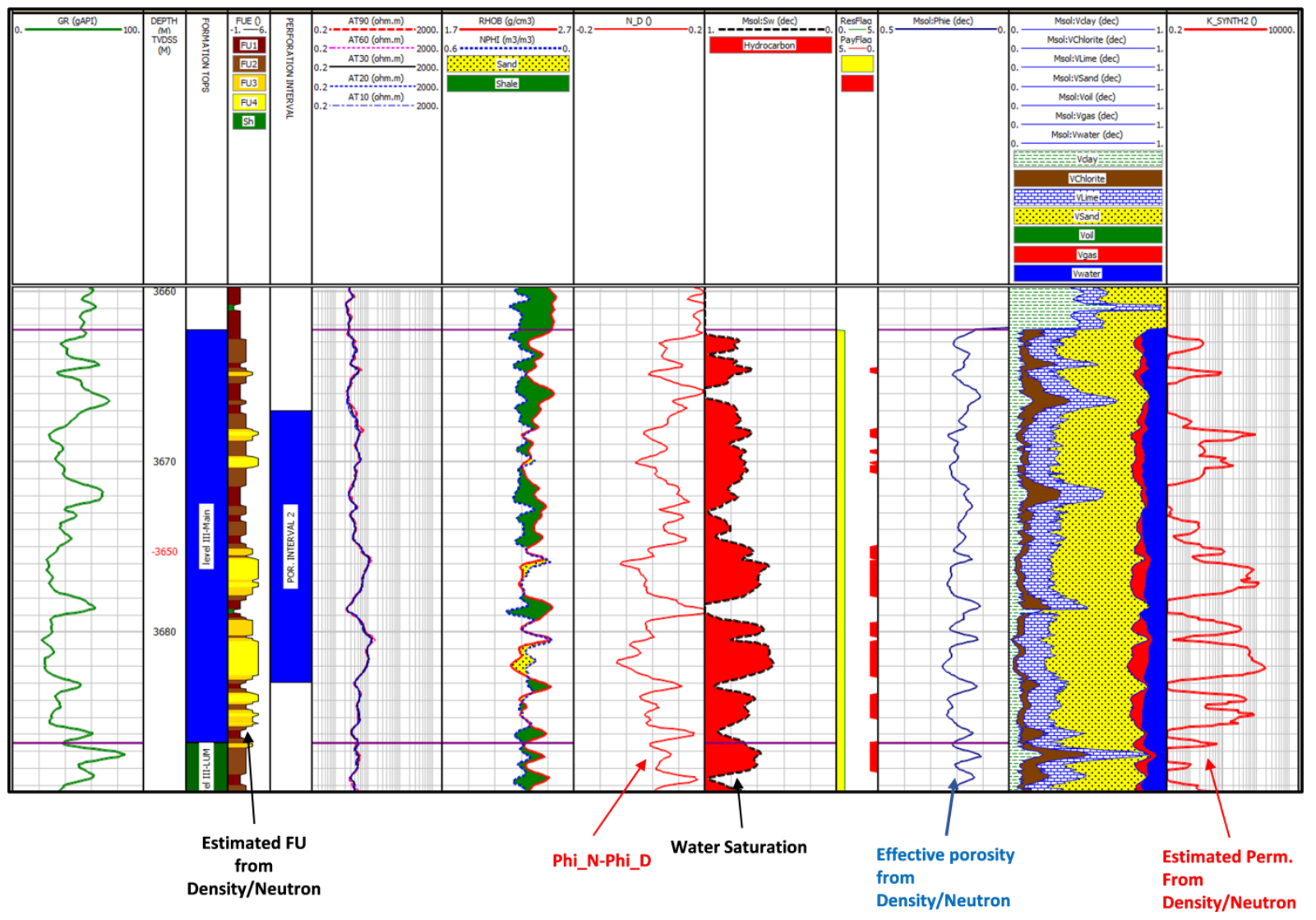

Figure 14. Estimated FU and permeability from Density-Neutron technique used for uncored well Baltim North-1. 
$\mathrm{BN}-2$
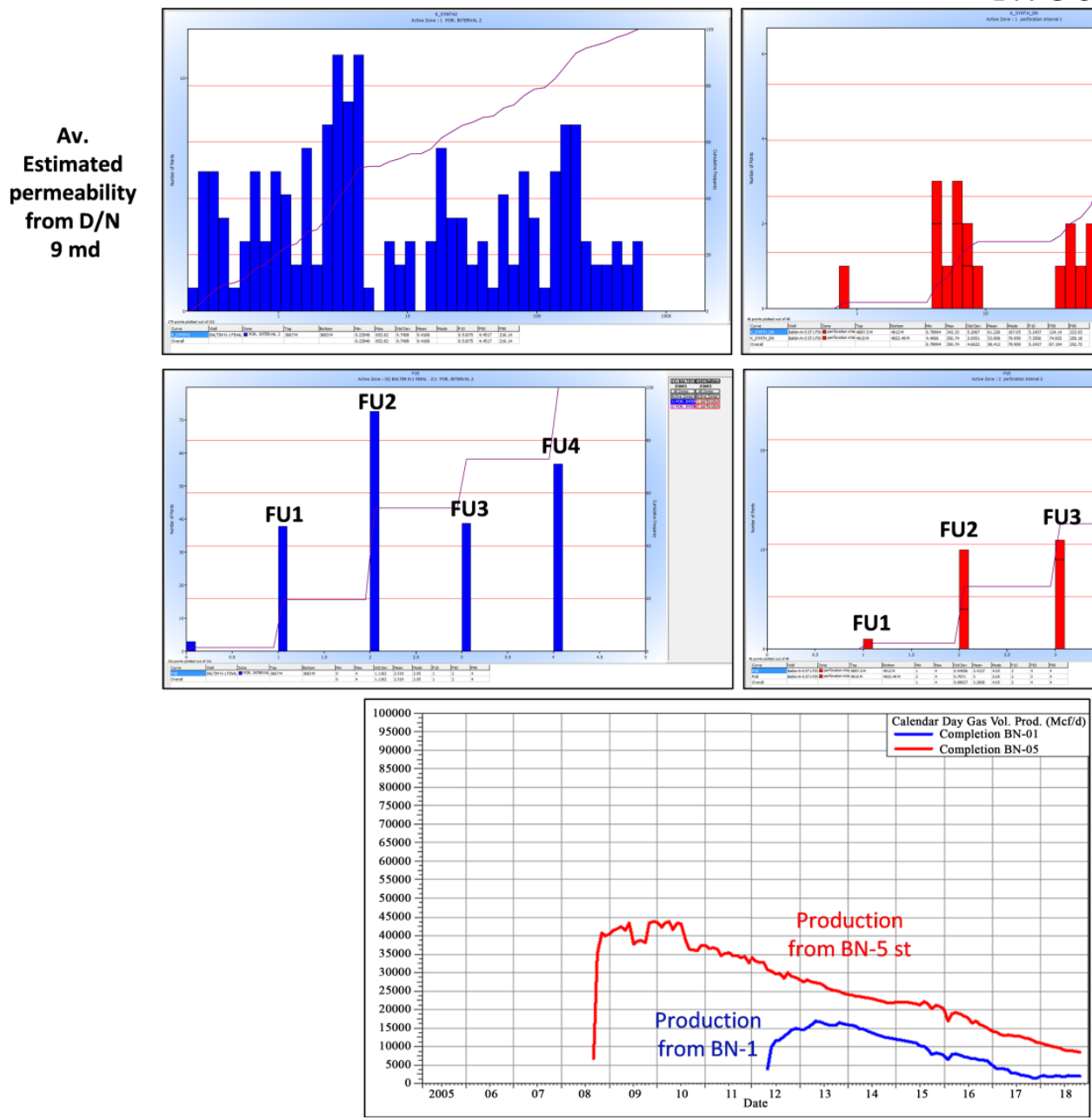

BN-5 st

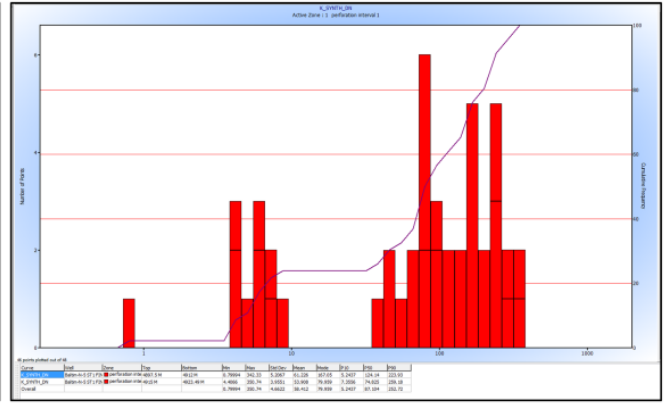

Av.

Estimated permeability from $D / N$ $58 \mathrm{md}$

Figure 15. Comparison between estimated FU, Permeability, and production in wells Baltim Norht- $5^{\text {th }}$ and Baltim North-1.

\section{Summary and Conclusions}

1) Based on the pore throat radius ( $r 35)$ calculation, the Baltim reservoir (level III main) in Baltim North- $5^{\text {th }}$ well has been subdivided into three flow units: FU4, FU3 and FU2 while in Baltim North-2 well, it was subdivided into four flow units: FU4, FU3, FU2 and FU1. The impact of the grain density is very clear on the permeability while, FU1 is characterized by high grain density and low permeability, FU4 has low grain density and high permeability however, the total porosity has almost of the same value. Permeability was Laboratory measured (Synthetic curve) for the two cored wells (Baltim North- $5^{\text {th }}$ and Baltim North-2) against the core intervals and the obtained results are closely match with the predicted permeability using N/D porosity technique. From the correlation between Flow Units and Density-Neutron logs in the cored well Baltim North- $5^{\text {th }}$, the FU4 was correlated with the high Density-Neutron separation, while the FU1 was correlated with the small separation.

2) Flow units have been estimated (EFU) from the relation between core porosity and the difference between (ØN - ØD) in the two cored wells Baltim 
North- $5^{\text {th }}$ and Baltim North-2.

3) The estimated flow units from $(\varnothing N-\varnothing D)$ were matched very close with the flow units from core measurements using Winland equation.

4) The permeability was predicted in the uncored reservoir intervals by use of EFU.

5) The estimated $\mathrm{FU}$ from $\mathrm{D} / \mathrm{N}$ against the perforated interval in well Baltim North-1 showing that most of the interval is related to FU2 while in well Baltim North- $5^{\text {th }}$ was related to FU4. The average permeability value in well Baltim North-1 was $9.0 \mathrm{mD}$ while, in well Baltim North $-5^{\text {th }}$ was $58.0 \mathrm{mD}$.

6) The actual production from un-cored well Baltim North-1 was lower than that from the cored well Baltim North- $5^{\text {th }}$.

\section{Acknowledgements}

The authors appreciate the Petrophysical Lab of Ain Shams University, Belayim Petroleum Company, Eni and EGAS for their support and the approval in publishing these materials.

\section{Conflicts of Interest}

The authors declare no conflicts of interest regarding the publication of this paper.

\section{References}

[1] El Sayed, A.M.A., Samy, Z., Lala, A. M. S., El Sayed, N.A. and Salah, A. (2020) Petrophysical Properties and Permeability Prediction for the Abu Madi Formation, Baltim North Gas Field, Nile Delta, Egypt. International Journal of Engineering Research and Development, 16, 15-36.

[2] El Heiny, I., Rizk, R. and Hassan, M. (1990) Sedimentological Mode for Abu Madi Reservoir Sands, Abu Madi Field, Nile Delta, Egypt. The 10th Petroleum Exploration Conference, Cairo, 515-551.

[3] Amaefule, J.O., et al. (1993) Enhanced Reservoir Description: Using Core and Log Data to Identify Hydraulic (Flow) Units and Predict Permeability in Uncored Intervals/Wells. SPE Annual Technical Conference and Exhibition, Houston, October 1993, 205-220. https://doi.org/10.2118/26436-MS

[4] Gunter, G.W., et al. (2014) Winland Pore Throat Prediction Method-A Proper Retrospect: New Examples from Carbonates and Complex Systems. SPWLA 55th Annual Logging Symposium, Chicago, 18-22 May 2014..

[5] Li, Y.Y., et al. (2015) Reservoir Classification and Evaluation Methods Based on R35 Pore Throat Radius. International Conference on Industrial Electronics and Applications, Shanghai, September 2015, 175-179. https://doi.org/10.2991/iea-15.2015.43

[6] Aguilera, R. (2002) Incorporating Capillary Pressure, Pore Aperture Radii, Height above Free Water Table, and Winland r35 Values on Pickett Plots. AAPG Bulletin, 86, 605-624. https://doi.org/10.1306/61EEDB5C-173E-11D7-8645000102C1865D

[7] El Sayed, A.M.A. (1981) Geological and Petrophysical Studies for the Algyo-2 Reservoir Evaluation, Algyo Oil and Gas Field. Ph.D. Thesis, Hungarian Academy of Sciences, Budapest, p.166.

[8] El Sayed, A.M.A. (2011) Thermophysical Study of Sandstone Reservoir Rocks. 
Journal of Petroleum Science and Engineering, 76, 138-147 https://doi.org/10.1016/j.petrol.2011.01.001

[9] El Sayed, A.M.A. and El Sayed, N.A. (2019) Thermal Conductivity Calculation from P-Wave Velocity and Porosity Assessment for Sandstone Reservoir Rocks. Geothermics, 82, 91-96 https://doi.org/10.1016/j.geothermics.2019.06.001

[10] El Sayed A.M.A. and El Sayed, N.A. (2016) Petrophysical Properties of Clastic Reservoirs Using NMR Relaxometry and Mercury Injection Data: Bahariya Formation, Egypt. International Journal of Geophysics and Geochemistry, 3, 28-32.

[11] Huang, H., Sun, W., Ji, W., Chen, L., Jiang, Z., Bai, Y., Tang, X., Du, K., Qu, Y. and Ouyang, S. (2018) Impact of Laminae on Gas Storage Capacity: A Case Study in Shanxi Formation, Xiasiwan Area, Ordos Basin, China. Journal of Natural Gas Science and Engineering, 60, 92-102. https://doi.org/10.1016/j.jngse.2018.09.001

[12] Winland, H.D. (1972) Oil Accumulation in Response to Pore Size Changes. In: Field, W., Ed., Amoco Production Research Report, No. F72-G-25, Saskatchewan.

[13] Martin, A.J., Solomon, S.T. and Hartmann, D.J. (1997) Characterization of Petrophysical Flow Units in Carbonate Reservoirs. AAPG Bulletin, 81, 734-759. https://doi.org/10.1306/522B482F-1727-11D7-8645000102C1865D 